\title{
METHYLENE BLUE FOR TREATMENT OF HOSPITALIZED COVID-19 PATIENTS: A RANDOMIZED, CONTROLLED, OPEN-LABEl Clinical TRIAL, PHASE 2
}

\author{
Daryoush Hamidi-Alamdari ${ }^{1 *}$, Saied Hafizi-LotfabadI ${ }^{2}$, Ahmad Bagheri-Moghaddam ${ }^{3}$, \\ Hossin Safari ${ }^{4}$, Mahnaz Mozdourian ${ }^{5}$, Zahra Javidarabshahi $^{5}$, Arash PeIVANDi-YaZdi ${ }^{5}$, \\ Abass Ali-Zeraati ${ }^{6}$, Alireza Sedaghat ${ }^{5}$, Farid Poursadegh ${ }^{5}$, Fatemeh Barazandeh-Ahmadabadi ${ }^{2}$, \\ Marzieh Agheli-Rad ${ }^{2}$, Seyed M. Tavousi ${ }^{6}$, Shohreh Vojouhi ${ }^{7}$, Shahram Amini $^{8}$, Mahnaz Amini $^{5}$, \\ Seyed Majid-Hosseini ${ }^{9}$, Ashraf Tavanaee-Sani ${ }^{10}$, Amin Ghiabi ${ }^{11}$, Shima Nabavi-Mahalli ${ }^{9}$, \\ Negar Morovatdar ${ }^{12}$, Omid Rajabi ${ }^{13}$, and George Koliakos ${ }^{14}$ \\ ${ }^{1}$ Surgical Oncology Research Center; ${ }^{2}$ Department of Internal Medicine, Shariati Hospital; ${ }^{3}$ Department of \\ Anesthesiology, Faculty of Medicine; ${ }^{4}$ Infectious Diseases Ward, Hasheminejad Hospital; ${ }^{5}$ Lung Diseases Research \\ Center; ${ }^{6}$ Kidney Transplantation Complications Research Center, Faculty of Medicine; ${ }^{7}$ Metabolic Syndrome \\ Research Center, School of Medicine; ${ }^{8}$ Anaesthesiology and Critical Care Lung Research Center, Faculty of Medicine; \\ ${ }^{9}$ Department of Internal Medicine, Emamreza Hospital; ${ }^{10}$ Department of Infectious diseases, Emamreza Hospital; \\ ${ }^{11}$ Department of Internal Medicine, Ghaem Hospital; ${ }^{12}$ Clinical Research Development Unit, Imam Reza Hospital, \\ Faculty of Medicine, and ${ }^{13}$ Department of Pharmaceutical Control, School of Pharmacy, Mashhad University of Medical \\ Sciences, Mashhad, Iran; ${ }^{14}$ Department of Biochemistry, Medical School, Aristotle University of Thessaloniki, \\ Thessaloniki, Greece
}

\begin{abstract}
Background: There is no pharmacological intervention on the treatment of hypoxemia and respiratory distress in COVID-19 patients. Objective: The objective of the study was to study the effect of the reduced form of methylene blue (MB) on the improvement of oxygen saturation $\left(\mathrm{SpO}_{2}\right)$ and respiratory rate (RR). Methods: In an academic medical center, 80 hospitalized patients with severe COVID-19 were randomly assigned to receive either oral MB along with standard of care (SOC) (MB group, $\mathrm{n}=40$ ) or SOC only (SOC group, $\mathrm{n}=40$ ). The primary outcomes were $\mathrm{SpO}_{2}$ and RR on the $3^{\text {rd }}$ and $5^{\text {th }}$ days. The secondary outcomes were hospital stay and mortality within 28 days. Results: In the MB group, a significant improvement in $\mathrm{SpO}_{2}$ and RR was observed on the $3^{\text {rd }}$ day (for both, $p<0.0001$ ) and also the $5^{\text {th }}$ day (for both, $p<0.0001$ ). In the SOC group, there was no significant improvement in $\mathrm{SpO}_{2}(p=0.24)$ and $\mathrm{RR}(\mathrm{p}=0.20)$ on the $3^{\text {rd }}$ day, although there was a significant improvement of $\mathrm{SpO}_{2}(p=0.002)$ and $\mathrm{RR}(\mathrm{p}=0.01)$ on the $5^{\text {th }}$ day. In the MB group in comparison to the SOC group, the rate ratio of increased $\mathrm{SpO}_{2}$ was 13.5 and 2.1 times on the $3^{\text {rd }}$ and $5^{\text {th }}$ days, respectively. In the MB group compared with the SOC group, the rate ratio of RR improvement was 10.1 and 3.7 times on the $3^{\text {rd }}$ and $5^{\text {th }}$ days, respectively. The hospital stay was significantly shortened in the MB group ( $p=0.004$ ), and the mortality was $12.5 \%$ and $22.5 \%$ in the MB and SOC groups, respectively. Conclusions: The addition of $\mathrm{MB}$ to the treatment protocols significantly improved $\mathrm{SpO}_{2}$ and respiratory distress in COVID-19 patients, which resulted in decreased hospital stay and mortality. ClinicalTrials.gov: NCT04370288 (REV INVEST CLIN. 2021;73(3):XX-XX)
\end{abstract}

Key words: COVID-19. Treatment. Methylene Blue. Hypoxemia. Mortality.

*Corresponding author:

Daryoush Hamidi Alamdari

E-mail: hamidiad@mums.ac.ir
Received for publication: 17-01-2021

Approved for publication: 08-03-2021

DOI: $10.24875 / R I C .21000028$

0034-8376 / (c) 2021 Revista de Investigación Clínica. Published by Permanyer. This is an open access article under the CC BY-NC-ND license (http://creativecommons.org/licenses/by-nc-nd/4.0/). 
Figure 1. Randomization and treatment assignment.

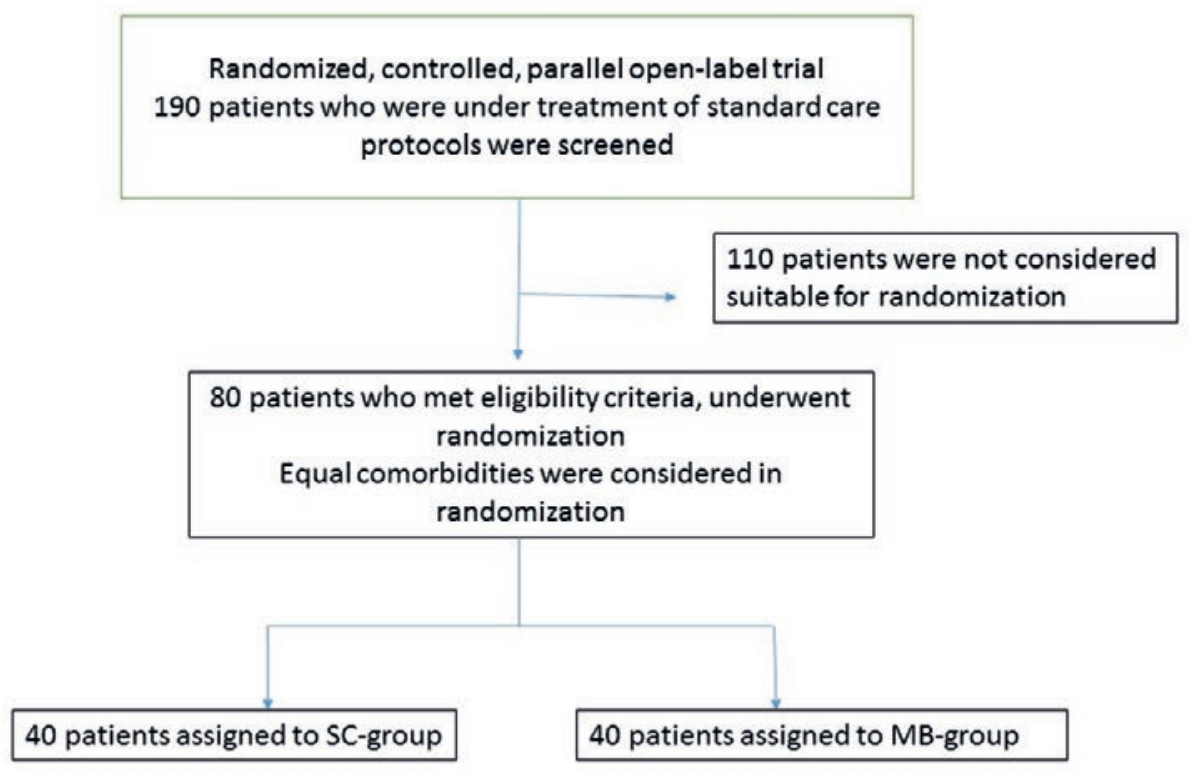

\section{INTRODUCTION}

For the treatment of severe COVID-19 patients, several therapeutic procedures have been suggested, with controversial results, although no attention has been paid to pharmacological intervention for the treatment of hypoxemia and respiratory distress. In severe cases, patients continue to have increased respiratory distress and hypoxemia despite a high percentage of oxygen therapy. For alleviating hypoxemia and respiratory distress, all attention have been focused on using only oxygen support by non-invasive or invasive ventilation ${ }^{1,2}$.

In our first trial, we explained in detail the possible pathogenesis of COVID-19 and the safety of methylene blue (MB) in the treatment of COVID-19 patients $^{3}$. There are two forms of $M B$, oxidized and reduced. The oxidized form is an oxidant that exacerbates oxidative stress; contrary, the reduced form (Leukomethylene [LMB]) is an antioxidant that alleviates oxidative stress. LMB (reduced form) decreases hypoxemia through its antioxidant effect, resulting in alleviating respiratory distress ${ }^{3-5}$. This trial was designed to evaluate the efficacy of $M B$ (the reduced form) for treating severe hospitalized COVID-19 patients by correcting hypoxemia and respiratory distress.

\section{METHODS}

\section{Study subjects}

The study was performed at three hospitals of Mashhad University of Medical Sciences, Mashhad, Iran, after ethics committee approval (IR.MUMS.REC.1399.122; ClinicalTrials.gov Identifier: NCT04370288; April 19, 2020) and taking written informed consent from patients. Enrollment for the clinical trial began on June 22, 2020, and ended on August 22, 2020. The authors were responsible for designing the trial and for collecting and analyzing the data. The clinical trial has been conducted according to the principles expressed in the Declaration of Helsinki.

\section{Study design}

This study was a randomized, controlled, parallel, open-label trial. Neither statistician nor investigators or patients were masked to the treatment assignment (Fig. 1). No drugs were masked, and a placebo was not used. Inclusion criteria were severe patients with age above 18 years old, respiratory distress ( $\geq 26$ breaths $/ \mathrm{min}$ ), oxygen saturation $\leq 93 \%$ at rest in the room $\left(\mathrm{FiO}_{2}=21\right)$, and a confirmed case of COVID-19 (by reverse transcription polymerase chain reaction on the nasopharyngeal swab collected or clinical and 
typical high-resolution computed tomography features), which had no sign of improvement after 5 days of the standard of care (SOC) treatment. Exclusion criteria were a history of G6PD deficiency, severe renal failure, body mass index more than $30 \mathrm{~kg} / \mathrm{m}^{2}$, cirrhosis, active chronic hepatitis, a history of an allergic reaction to $M B$, treatment with immunosuppressive agents, pregnancy, breastfeeding, and the presence of any condition that would not allow the protocol to be followed safely, such as cognitive impairments or poor mental status.

To achieve the sample size of 80,190 hospitalized patients were screened (Fig. 1). To decrease the effect of confounding factors, cluster randomization was performed to equalize comorbidities in each group. Eligible patients were randomly included and stratified by their pre-existing conditions in a 1:1 ratio to either the MB group (40 patients) or the SOC group (40 patients).

\section{METHODS}

\section{MB syrup formulation}

The syrup contained $M B$, Vitamin $C$, dextrose, and $\mathrm{N}$-acetyl cysteine. The special formulation for MB (the reduced form) was patented (IR139950140003002083) (on June 1, 2020, PCT). The syrup was made by dissolving MB (USP) (14 mg/ $\mathrm{mL}$ ) in a simple syrup ( $50 \%$ sucrose). The electrochemical reduction process was performed in the presence of dextrose $\left(500 \mathrm{mg} / \mathrm{mL}\right.$, at $\left.70^{\circ} \mathrm{C}, 40 \mathrm{~min}\right)$, Vitamin $\mathrm{C}\left(140 \mathrm{mg} / \mathrm{mL}\right.$ at $\left.30^{\circ} \mathrm{C}, 50 \mathrm{~min}\right)$, and $\mathrm{N}$ acetyl cysteine $\left(150 \mathrm{mg} / \mathrm{mL}\right.$ at $\left.30^{\circ} \mathrm{C}, 50 \mathrm{~min}\right)$. In this study, the conversion index of MB to LMB was almost zero absorption in the wavelength of $660 \mathrm{~nm}$, when the syrup was diluted to a concentration of $4 \mathrm{mg} / \mathrm{L}$ in distilled water. Accelerated stability studies $\left(40^{\circ} \mathrm{C}\right.$ $\pm 2^{\circ} \mathrm{C}$ ) were done for a period of 3 months and no significant changes were observed during this time. However, all drugs were used within 3 months.

\section{Intervention}

In the MB group, along with SOC, MB syrup was administered orally to patients $(1 \mathrm{mg} / \mathrm{kg}$ every $8 \mathrm{~h}$ for 2 days, followed by $1 \mathrm{mg} / \mathrm{kg}$ every $12 \mathrm{~h}$ for the following 12 days). In the SOC group, SOC protocol was continued. SOC protocols were applied according to the WHO guidelines. In SOC protocols, severely ill patients receive supplemental oxygen, intravenous fluids, antiviral agents, antibiotics, anticoagulants, and corticosteroids ${ }^{6,7}$.

During MB therapy, patients were assessed on each visit for oxygen saturation $\left(\mathrm{SpO}_{2}\right)$ and respiratory rate (RR, number of breaths per minute) at rest in the room air $\left(\mathrm{FiO}_{2}=21\right)$ after lunch. The primary outcomes were $\mathrm{SpO}_{2}$ level and RR on the $3^{\text {rd }}$ and $5^{\text {th }}$ days. The secondary outcomes were hospital stay and mortality rate within 28 days. It should be noted that hospital stay was counted from the day after MB treatment. Decrease in RR was considered as improvement of respiratory distress.

\section{Statistical analysis}

Continuous variables were compared by the MannWhitney U-test. Furthermore, Chi-square and Fisher's exact tests were used for categorical variables. The mean difference of $\mathrm{SpO}_{2}$ and RR was calculated for each study group. The Wilcoxon rank sign test was used to compare the mean difference of these variables for each study group. The significance level was $<0.05$ in all statistical analyses. SPSS version 23 was used in statistical analysis. The rate ratio calculation for $\mathrm{SpO}_{2}$ (or RR) on the $3^{\text {rd }}$ day was the mean difference of $\mathrm{SpO}_{2}$ (or RR) on the $3^{\text {rd }}$ day in the $\mathrm{MB}$ group divided by the mean difference of $\mathrm{SpO}_{2}$ (or RR) on the $3^{\text {rd }}$ day in the $\mathrm{SOC}$ group. The rate ratio calculation for $\mathrm{SpO}_{2}$ (or RR) on the $5^{\text {th }}$ day was the mean difference of $\mathrm{SpO}_{2}$ (or RR) on the $5^{\text {th }}$ day in the $\mathrm{MB}$ group divided by the mean difference of $\mathrm{SpO}_{2}$ (or RR) on the $5^{\text {th }}$ day in the SOC group.

\section{Role of the funding source}

The funders did not have any role on the design, collection, management, analysis, interpretation of data, writing of the report, or the decision to submit the report for publication. This work was supported by a grant from Mashhad University of Medical Sciences (Grant number: 990096).

Ethics approval statement IR.MUMS.REC.1399.122; Clinical Trials.gov Identifier: NCT04370288; April 19, 2020. 
Table 1. Baseline patient characteristics of methylene plus standard of care group (MBG) and SOC group (SCG)

\begin{tabular}{|c|c|c|c|}
\hline Patients & $\begin{array}{c}\text { MBG } \\
(n=40)\end{array}$ & $\begin{array}{c}\text { SCG } \\
(n=40)\end{array}$ & SD \\
\hline Age & $53 / 7 \pm 13 /$ & $55 / 2 \pm 13 / 8$ & $\mathrm{n}, \mathrm{p}=0.8$ \\
\hline Male/female & $19 / 21$ & $23 / 17$ & $\mathrm{n}, \mathrm{p}=0.3$ \\
\hline $\begin{array}{l}\text { Antivirals (hydroxychloroquine }+ \\
\text { Kaletra) (5 days) }\end{array}$ & 100 & 100 & \\
\hline \multicolumn{4}{|l|}{ Antibiotic } \\
\hline Ceftriaxone (7 days) & $70 \%$ & $75 \%$ & $n, p=0.9$ \\
\hline Azithromycin (5 days) & $95 \%$ & $90 \%$ & \\
\hline Meropenem ( $7-10$ days) & $30 \%$ & $25 \%$ & \\
\hline Vancomycin (7-10 days) & $30 \%$ & $25 \%$ & \\
\hline \multicolumn{4}{|l|}{ Anticoagulant (up to discharge) } \\
\hline Prophylactic & $85 \%$ & $90 \%$ & $n, p=0.9$ \\
\hline Therapeutic & $10 \%$ & $5 \%$ & \\
\hline \multicolumn{4}{|l|}{ No anticoagulant } \\
\hline $\begin{array}{l}\text { Immunosuppressant and } \\
\text { Immunomodulatory agents }\end{array}$ & $5 \%$ & $5 \%$ & $\mathrm{n}, \mathrm{p}=0.9$ \\
\hline Dexamethasone (10 days) & $90 \%$ & $85 \%$ & \\
\hline Atorvastatin (up to discharge) & $95 \%$ & $90 \%$ & \\
\hline Interferon beta (3-5 days) & $30 \%$ & $35 \%$ & \\
\hline \multicolumn{4}{|l|}{ Comorbidities } \\
\hline No medical history & 16 & 18 & $\mathrm{n}, \mathrm{p}=0.9$ \\
\hline Hypertension & 7 & 7 & \\
\hline Diabetes & 3 & 5 & \\
\hline Diabetes + Hypertension & 7 & 7 & \\
\hline Others & $5^{*}$ & $5 \#$ & \\
\hline
\end{tabular}

*One patient: Down's syndrome; one patient: rheumatoid arthritis; one patient: Gout disease; one patient: coronary artery bypass graft; one patient: hypothyroidism, kidney stone, ischemic heart disease.

\#One patient: coronary artery bypass graft, one patient: breast cancer; one patient: lymphoma; one patient: prostate cancer; one patient: ischemic heart disease.

SD: significant difference; SOC: standard of care.

\section{RESULTS}

\section{Patients}

Demographic characteristics of patients in the MB and $\mathrm{SOC}$ groups are presented in Table 1 . There were no significant differences in demographic characteristics between both groups.

\section{Primary outcomes}

In the MB group, patients had a significant increase of $\mathrm{SpO}_{2}$ on the $3^{\text {rd }}$ day (mean difference [MD]: $5.4 ; 95 \%$ confidence interval [Cl]: 3.4-7.4; $\mathrm{p}<0.0001$ ) and on the $5^{\text {th }}$ day (MD: 8.9, 95\% Cl: $5.5-12.2 ; \mathrm{p}<0.0001$ ). In the SOC group, there was no significant increase in $\mathrm{SpO}_{2}$ on the $3^{\text {rd }}$ day (MD: $0.4,95 \% \mathrm{Cl}:-0.3-1.294$; $\mathrm{p}=0.24)$; however, patients had a significant increase in $\mathrm{SpO}_{2}$ on the $5^{\text {th }}$ day (MD: $4.3,95 \% \mathrm{Cl}: 1.8-$ $6.9 ; p=0.001$ ) (Table 2).

In the MB group, patients had a significant decrease of RR on the $3^{\text {rd }}$ day (MD: $-9.1,95 \% \mathrm{Cl}:-11.0--7.1$; $\mathrm{p}<0.0001)$ and on the $5^{\text {th }}$ day (MD: $-11.6,95 \% \mathrm{Cl}$ : $-14.7--8.5 ; p<0.0001$ ). In the SOC group, patients had no significant decrease of RR on the $3^{\text {rd }}$ day (MD: 
Table 2. Changes of oxygen saturation $\left(\mathrm{SpO}_{2}\right)$ and RR in MBG and SCG groups

\begin{tabular}{|c|c|c|c|c|c|c|c|}
\hline $\mathrm{SpO}_{2}$ & Before MB & $\begin{array}{l}3^{\text {rd }} \text { day } \\
\text { fter MB }\end{array}$ & $\begin{array}{l}5^{\text {th }} \text { day } \\
\text { after MB }\end{array}$ & RR & $\begin{array}{c}\text { Before } \\
\text { MB }\end{array}$ & $\begin{array}{c}3^{\text {rd day }} \\
\text { after MB }\end{array}$ & $\begin{array}{l}5^{\text {th }} \text { day } \\
\text { after MB }\end{array}$ \\
\hline MBG & $80.0 \pm 9.3$ & $\begin{array}{c}85.4 \pm 7.8 \\
\text { a: } y p<0 / 0001\end{array}$ & $\begin{array}{c}88.9 \pm 9.8 \\
\text { b: } y p<0 / 0001\end{array}$ & $\mathrm{MBG}$ & $34.4 \pm 5.5$ & $\begin{array}{c}25.3 \pm 4 / 4 \\
\text { a: } y p<0 / 0001\end{array}$ & $\begin{array}{c}22.7 \pm 6.7 \\
\text { b: } y p<0 / 0001\end{array}$ \\
\hline SCG & $79.8 \pm 7.5 C$ & $\begin{array}{c}80.2 \pm 7.4 \\
a: n p=0.24\end{array}$ & $\begin{array}{c}84.1 \pm 9.7 \\
\text { b: y } p=0.002\end{array}$ & SC-G & $32.0 \pm 4.8 d$ & $\begin{array}{c}31.1 \pm 4.3 \\
\mathrm{a}: \mathrm{n} p=0.20\end{array}$ & $\begin{aligned} 28.8 & \pm 5.8 \\
b: y p & =0.01\end{aligned}$ \\
\hline
\end{tabular}

Data are presented as mean \pm SD (standard deviation).

asignificant difference (SD) between the $3^{\text {rd }}$ day after and before MB therapy.

bSignificant difference (SD) between the $5^{\text {th }}$ day after and before MB therapy.

$\mathrm{y}$ : yes; $\mathrm{n}$ : no; there was no significant difference of $\mathrm{SpO}_{2}$

(c: $p=0.461)$ and RR (d: $p=0.1$ ) between MBG and SCG before MB therapy. RR: respiratory rate.

Table 3. Comparison of oxygen saturation ( $\mathrm{SpO} 2$ ) and RR between MBG and SCG groups

\begin{tabular}{|c|c|c|c|}
\hline $\mathrm{SpO}_{2} \& \mathrm{RR}$ & MBG & SCG & $\mathrm{p}^{*}$ \\
\hline Median $\mathrm{SpO}_{2}$ baseline & $\begin{array}{c}83.5 \\
(73.5-88)\end{array}$ & $\begin{array}{c}82 \\
(74.2-85)\end{array}$ & 0.46 \\
\hline $\begin{array}{l}\text { Median } \mathrm{SpO}_{2} \text { on } 3^{\text {rd }} \text { days } \\
\text { after intervention }\end{array}$ & $\begin{array}{c}89 \\
(83.25-90.75)\end{array}$ & $\begin{array}{c}82 \\
(76.25-86)\end{array}$ & $<0.001$ \\
\hline $\begin{array}{l}\text { Median } \mathrm{SpO}_{2} \text { on } 5 \text { days } \\
\text { after intervention }\end{array}$ & $\begin{array}{c}93 \\
(88-95)\end{array}$ & $\begin{array}{c}87 \\
(80.25-91.75)\end{array}$ & 0.01 \\
\hline $\begin{array}{l}\text { Mean difference of } \mathrm{SpO}_{2} \\
\text { after } 3 \text { days }\end{array}$ & $\begin{array}{c}4 \\
(2-8.75)\end{array}$ & $\begin{array}{c}1 \\
(-2-2.75)\end{array}$ & $<0.001$ \\
\hline $\begin{array}{l}\text { Mean difference of } \mathrm{SpO}_{2} \\
\text { after } 5 \text { days }\end{array}$ & $\begin{array}{c}7 \\
(6-14)\end{array}$ & $\begin{array}{c}6 \\
(1-10)\end{array}$ & 0.05 \\
\hline $\begin{array}{l}\text { Median respiratory rate } \\
\text { baseline }\end{array}$ & $\begin{array}{c}35.5 \\
(29.2-39)\end{array}$ & $\begin{array}{c}31.5 \\
(28.2-35)\end{array}$ & 0.07 \\
\hline $\begin{array}{l}\text { Median respiratory rate on the } \\
3^{\text {rd }} \text { days after intervention }\end{array}$ & $\begin{array}{c}25 \\
(21-28.7)\end{array}$ & $\begin{array}{c}30.5 \\
(28-34.7)\end{array}$ & $<0.001$ \\
\hline $\begin{array}{l}\text { Median respiratory rate on } 5 \text { days } \\
\text { after intervention }\end{array}$ & $\begin{array}{c}21 \\
(18.2-23)\end{array}$ & $\begin{array}{c}28.5 \\
(24-33.75)\end{array}$ & $<0.001$ \\
\hline $\begin{array}{l}\text { Mean difference of respiratory } \\
\text { rate after } 3 \text { days }\end{array}$ & $\begin{array}{c}-10 \\
(-12--5)\end{array}$ & $\begin{array}{c}-3 \\
(-4-3)\end{array}$ & $<0.001$ \\
\hline $\begin{array}{l}\text { Mean difference of respiratory } \\
\text { rate after } 5 \text { days }\end{array}$ & $\begin{array}{c}-13.5 \\
(-17.7--9)\end{array}$ & $\begin{array}{c}-4 \\
(-8-2)\end{array}$ & $<0.001$ \\
\hline
\end{tabular}

Data are presented by median (interquartile range).

*Mann-Whitney U-test.

RR: respiratory rate.

$-0.9,95 \% \mathrm{Cl}:-2.6-0.6 ; \mathrm{p}=0.20)$, but there was a significant decrease of RR on the $5^{\text {th }}$ day (MD: -3.1 , 95\% Cl: -5.4--0.8; $\mathrm{p}=0.01$ ) (Table 2).

The mean differences of $\mathrm{SpO}_{2}$ and RR changes were higher in the MB group compared with the SOC group on the $3^{\text {rd }}$ and $5^{\text {th }}$ days (Table 3 and Fig. 2). In the MB group in comparison to the SOC group, the rate ratio of increased $\mathrm{SpO}_{2}$ was 13.5 and 2.1 times on the $3^{\text {rd }}$ and $5^{\text {th }}$ days, respectively. In the $\mathrm{MB}$ group in comparison to the SOC group, the rate ratio of $\mathrm{RR}$ improvement was 10.1 and 3.7 times on the $3^{\text {rd }}$ and $5^{\text {th }}$ days, respectively.

\section{Secondary outcomes}

After MB therapy, the hospital stay was significantly shortened in the MB group compared with the SOC group (MD: $-3.8,95 \% \mathrm{Cl}:-6.3--1.2 ; \mathrm{p}=0.004$ ). The mortality rate in the $\mathrm{MB}$ and SOC groups was $12.5 \%$ and $22.5 \%$, respectively (Table 4 ). The change in 
Figure 2. Comparison of oxygen saturation $\left(\mathrm{A}: \mathrm{SpO}_{2}\right)$ and respiratory rate (B: RR) between MBG and SCG groups during follow-up. A: $\mathrm{SpO}_{2} ; \mathrm{B}: \mathrm{RR}$.

\section{A $\mathrm{SpO} 2$}

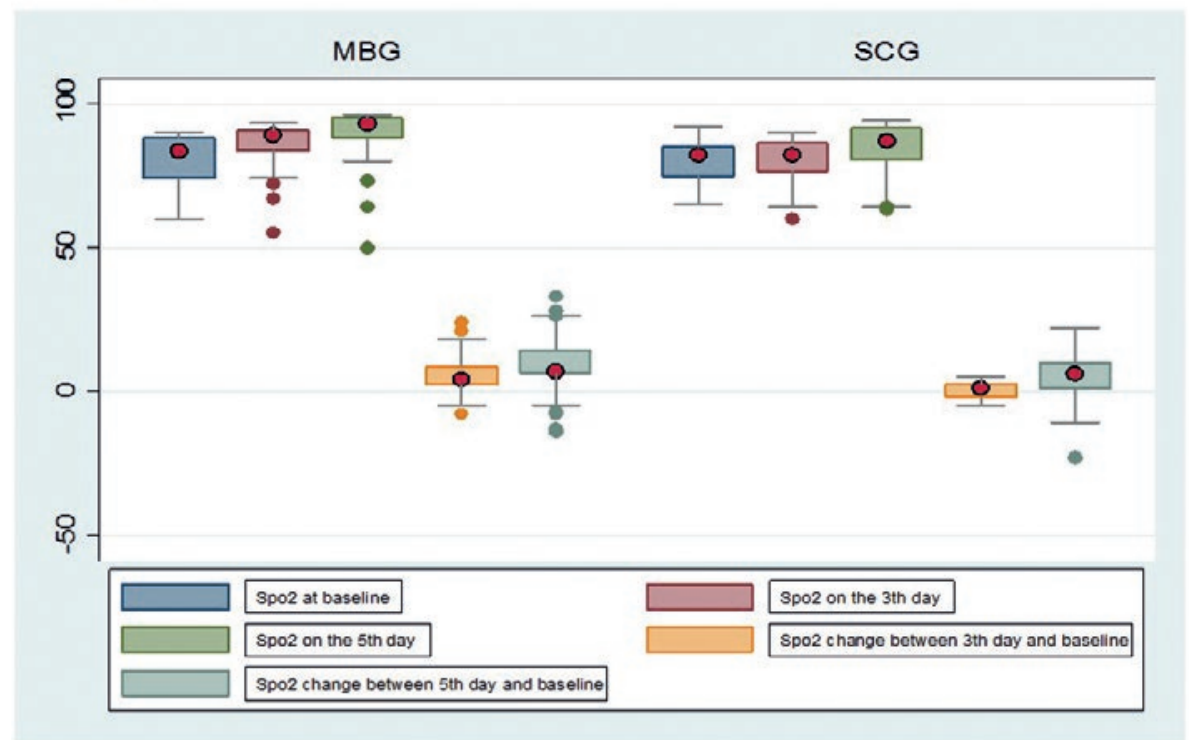

\section{B RR}

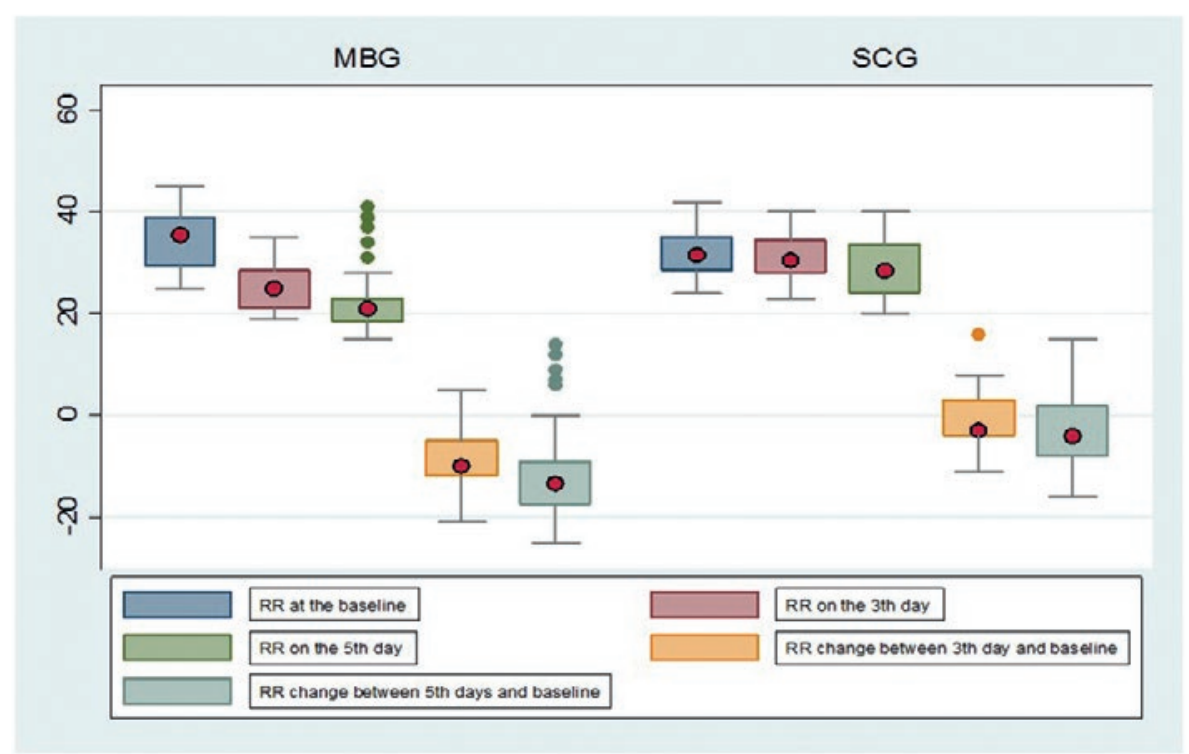

mortality rate was not significant (MD: $-0.10,95 \%$ $\mathrm{Cl}:-0.27-0.06 ; \mathrm{p}=0.24$ ), but it was reduced by $10 \%$. No serious adverse effects were observed in the MB group except for the color of the patients' urine, which turned to green or blue.

\section{Side effects of MB}

The side effects of MB were one patient with a very light headache that resolved after $10 \mathrm{~min}$; and one patient who vomited after using $M B$, and then did 
Table 4. Hospital stay and mortality rate in MBG and SCG groups

\begin{tabular}{|c|c|c|c|}
\hline Patients & $\begin{array}{c}\text { MBG } \\
(n=40)\end{array}$ & $\begin{array}{c}\text { SCG } \\
(n=40)\end{array}$ & SD \\
\hline Hospital stay* (days) & $7.3 \pm 4.7$ & $11.7 \pm 6.6$ & $y p=0 / 004$ \\
\hline Day $28^{\text {th }}$ : mortality $n(\%)$ & $\begin{array}{c}5 \\
(12.5 \%)\end{array}$ & $\begin{array}{c}9 \\
(22.5 \%)\end{array}$ & $\mathrm{np}=0.24$ \\
\hline
\end{tabular}

*Patients were under treatment for 5 days and did not improve, and then, MB therapy started. The hospital stay was counted from the day after MB treatment.

$\mathrm{N}$ : number of dead patients; SD: significant difference; y: yes; n: no.

Table 5. The blood count, liver enzymes, and kidney function tests at the beginning and at the end of MB therapy

\begin{tabular}{lccc}
\hline Test & $\begin{array}{c}\text { Before } \\
\text { MBT }\end{array}$ & $\begin{array}{c}\text { After } \\
\text { MBT }\end{array}$ & $\begin{array}{c}\text { Significant difference } \\
\text { p-value }\end{array}$ \\
\hline Urea & $39.0 \pm 17.9$ & $44.5 \pm 14.4$ & No, 0.2 \\
Creatinine & $0.93 \pm 0.17$ & $0.86 \pm 0.19$ & No, 0.16 \\
ALT & $58.1 \pm 105.5$ & $72.4 \pm 78.5$ & No, 0.59 \\
AST & $67.4 \pm 103.8$ & $55.3 \pm 59.1$ & No, 0.60 \\
WBC & $8.2 \pm 4.1$ & $8.6 \pm 4.5$ & No, 0.77 \\
PMN & $81.2 \pm 9.7$ & $80.5 \pm 6.5$ & No, 0.74 \\
Lymphocyte & $12.1 \pm 7.1$ & $13.3 \pm 6.2$ & No, 0.51 \\
\hline
\end{tabular}

MBT: methylene blue therapy; WBC: white blood cell; PMN: polymorphonuclear; ALT: alanine aminotransferase; AST: aspartate transaminase. MB: methylene blue.

not consent to take part in the trial. Confusion, increase in blood pressure, and shortness of breath were not seen among the patients. These findings may be related to the fact that reduced $M B$ was used instead of oxidized MB; further research could clarify this matter. To rule out toxic effects of $M B$, blood count, liver enzymes, and kidney function tests at the start and the end of MB therapy were compared (Table 5).

\section{DISCUSSION}

This trial showed that $\mathrm{MB}$, as a supplementary therapy to SOC protocols, led to a significant increase in $\mathrm{SpO}_{2}$, a significant decrease of respiratory distress and hospital stay, and $10 \%$ decrease in mortality rate. Severe COVID-19 patients presented with the chief complaint of dyspnea. After 1 day of MB administration, $92 \%$ of patients expressed dyspnea relief. This finding was very important for the care of COVID-19 patients suffering from respiratory distress.
In the MB group, the history of patients who had died highlighted that the best time for $M B$ intervention was at the early stages of hypoxemia before requiring mechanical ventilation. The change in mortality rate was not significant (although there was a decrease of $10 \%$ ), which may have been due to the small number of patients in this study.

In our previous trial, we discussed one of the possible biochemical processes which may be involved in the pathogenesis of the disease. It is the activation of macrophages by viruses that produce a huge amount of nitric oxide (NO). NO takes part in producing the highly reactive oxygen species (ROS) and also is converted to nitrite in blood by ceruloplasmin. ROS and nitrite pass easily through the red blood cell membrane and oxidize ferrous to ferric. Oxygen cannot attach to ferric ion in hemoglobin (methemoglobin) which results in hypoxemia ${ }^{3}$.

The rationale for considering $\mathrm{MB}$ for treatment was the following proven mechanisms: (1) MB has antiviral 
activity against COVID-19 by inhibiting in vitro the severe acute respiratory syndrome coronavirus-2 (SARS-CoV-2) spike-ACE2 protein-protein interaction $^{8}$. MB can prevent the cytopathic effect and reduce the propagation of RNA virus ${ }^{9}$. (2) MB is an FDA-approved drug in the treatment of methemoglobinemia $^{10}$. (3) MB has direct inhibitory effects on NO synthases (produces NO that takes part in generating reactive nitrogen species, which damage the cells and biomolecules) and guanylate cyclase enzyme ${ }^{11}$. (4) $\mathrm{MB}$ increases the activity of normally slow NADPHmethemoglobin reductase pathway, which decreases hypoxemia through reducing methemoglobin ${ }^{12}$. (5) $M B$ has formed the basis of antimicrobial chemotherapy, particularly in the area of antimalarials. It is used in an antibacterial foam dressing for the management of chronic wounds with local infection ${ }^{13}$. (6) MB is a powerful oxygen superoxide scavenger that eliminates rapidly this ion to avoid damage to tissue ${ }^{14}$. (7) MB inhibits xanthine oxidase, which prevents ROS production $^{15}$. (8) MB prevents platelet activation, adhesion, and aggregation ${ }^{16}$. (9) MB (the reduced form) quenches ROS as a reducing agent ${ }^{17}$. (10) MB (the reduced form) decreases inflammation ${ }^{18}$.

In this study, after the administration of MB (the reduced form, colorless), the color of urine and feces of patients turned to green or blue. Patients whose urine or feces had the green color, recovered (35 patients), but five patients who had dark blue color in urine or feces died. In our previous trial, we demonstrated high oxidative stress in COVID-19 patients $^{3}$. When MB (oxidized form, dark blue) is orally administered, by oxidizing other antioxidants, it is converted to the reduced form (colorless) ${ }^{19}$, which is excreted primarily in the urine ${ }^{20}$. Therefore, the oxidized form of $M B$ exacerbates the oxidative stress in COVID-19 patients, worsening hypoxemia. However, the reduced form of MB, as an antioxidant, quenches the oxidative stress and also decreases hypoxemia by converting the ferric to the ferrous ion in hemoglobin. In this trial, after the administration of $M B$ (the reduced form), since there were a large number of oxidants in patients $^{3}$, they oxidized the reduced form of $M B$ (LMB) and turned it to the oxidized form, which was excreted in the urine in blue color. Dark blue in the urine reflected high oxidative stress in patients. This phenomenon could be considered as a prognostic factor; patients whose urine turns to a dark blue color usually have a worse outcome which requires more advanced intervention. These patients may need a cocktail of antioxidants along with the reduced form of MB.

Limitations of the study include that the trial was conducted in one university center with a small number of patients.

MB therapy along with SOC may be efficacious in the treatment of COVID-19. This supplementary treatment may improve patient outcomes (increasing $\mathrm{SpO}_{2}$ and decreasing respiratory distress, hospital stay, and mortality rate) without serious adverse effects. MB is an FDA-approved drug for methemoglobinemia. Since $M B$ is inexpensive and ubiquitously accessible, this drug may be used as a supplementary choice for the treatment of hypoxemia in COVID-19 patients. We suggest that the ideal time for MB administration should be on diagnosis and at least before the severe stage of the disease and multiorgan involvement and failure. MB may also be used for prevention, since it can protect the population by inhibiting the SARS-CoV-2 spike-ACE2 interaction ${ }^{8}$, and can also reduce the propagation of RNA virus ${ }^{9}$. If the findings of this trial are verified by larger clinical trials and other research centers, it could save COVID-19 patients from stressful respiratory distress and can reduce hospital stay and mortality.

\section{ACKNOWLEDGMENTS}

The authors gratefully acknowledge Mehdi Dehghan, Freshteh Dolatkhah, Moslem Faraji Shandiz, Seyed Ali Golabgiran, Malihe Mokhtarzadeh, Fateme Kiani, Azam Dehghan, Mohamad Nadafan and Hosein Kafshgarin from Imam Reza Hospital, Shariati Hospital, and Hasheminejad Hospital, for their excellent cooperation.

\section{REFERENCES}

1. Shenoy N, Luchtel R, Gulani P. Considerations for target oxygen saturation in COVID-19 patients: are we under-shooting? BMC Med. 2020;18:1-6.

2. Perkins GD, Couper K, Connolly B, Baillie JK, Bradley JM, Dark P, et al. RECOVERY - respiratory support: respiratory strategies for patients with suspected or proven COVID-19 respiratory failure; continuous positive airway pressure, high-flow nasal oxygen, and standard care: a structured summary of a study protocol for a randomised controlled trial. Trials. 2020;21:687.

3. Alamdari DH, Moghaddam AB, Amini S, Keramati MR, Zarmehri $\mathrm{AM}$, Alamdari $\mathrm{AH}$, et al. Application of methylene blue -vitamin 
C -N-acetyl cysteine for treatment of critically ill COVID-19 patients, report of a phase-I clinical trial. Eur J Pharmacol. 2020; 885:173494.

4. Oz M, Lorke DE, Hasan M, Petroianu GA. Cellular and molecular actions of methylene blue in the nervous system. Med Res Rev. 2011;31:93-117

5. May JM, Qu ZC, Whitesell RR. Generation of oxidant stress in cultured endothelial cells by methylene blue: protective effects of glucose and ascorbic acid. Biochem Pharmacol. 2003; 66:777-84.

6. Smith T, Bushek J, LeClaire A, Prosser T. COVID-19 Drug Therapy, Clinical Drug Information, Clinical Solutions. Amsterdam: Elsevier; 2020.

7. Janssen DJ, Ekström M, Currow DC, Johnson MJ, Maddocks M Simonds AK, et al. COVID-19: guidance on palliative care from a European Respiratory Society international task force. Eur Respir J. 2020;56:2002583.

8. Bojadzic D, Alcazar O, Buchwald P. Methylene blue inhibits the SARS-CoV-2 spike-ACE2 protein-protein interaction-a mechanism that can contribute to its antiviral activity against COVID-19. Front Pharmacol. 2021;11:600372.

9. Kovacs E. Prevention of cytopathic effect and propagation of poliovirus by methylene blue. Z Naturforsch B. 1960;15B: 588-92.

10. Chan DS, Yang $H$, Kwan $M H$, Cheng Z, Lee $P$, Bai LP, et al Structure-based optimization of FDA-approved drug methylene blue as a c-myc G-quadruplex DNA stabilizer. Biochimie. 2011; 93:1055-64.

11. Mayer B, Brunner F, Schmidt K. Inhibition of nitric oxide synthesis by methylene blue. Biochem Pharmacol. 1993;26:367-74.
12. McPherson RA. Henry's Clinical Diagnosis and Management by Laboratory Methods: First South Asia Edition. India: Elsevier; 2017.

13. Woo KY, Heil J. A prospective evaluation of methylene blue and gentian violet dressing for management of chronic wounds with local infection. Int Wound J. 2017;14:1029-35.

14. Riedel $W$, Lang $U$, Oetjen U, Schlapp U, Shibata M Inhibition of oxygen radical formation by methylene blue, aspirin, or alphalipoic acid, prevents bacterial-lipopolysaccharide-induced fever. Mol Cel Biochem. 2003;247:83-94.

15. Salaris SC, Babbs CF, Voorhees WD. Methylene blue as an inhibitor of superoxide generation by xanthine oxidase. A potential new drug for the attenuation of ischemia/reperfusion injury. Biochem Pharmacol. 1991;42:499-506.

16. Miclescu A, Wiklund L. Methylene blue, an old drug with new indications. J Rom Anest Terap Int. 2010;17:35-41.

17. Haynes RK, Chan WC, Wong HN, Li KY, Wu WK, Fan KM, et al. Facile oxidation of leucomethylene blue and dihydroflavins by artemisinins: relationship with flavoenzyme function and antimalarial mechanism of action. ChemMed Chem. 2010;5: 1282-99.

18. Lin ZH, Wang SY, Chen LL, Zhuang JY, Ke QF, Xiao DR, et al. Methylene blue mitigates acute neuroinflammation after spinal cord injury through inhibiting NLRP3 inflammasome activation in microglia. Front Cell Neurosci. 2017;11:391.

19. May JM, Qu ZC, Cobb CE. Reduction and uptake of methylene blue by human erythrocytes. Am J Physiol Cell Physiol. 2004; 286:C1390-8.

20. Prakash S, Saini S, Mullick P, Pawar M. Green urine: a cause for concern? J Anaesthesiol Clin Pharmacol. 2017;33:128-30. 